\title{
Pengaruh Model Pembelajaran Problem Solving Laboratory Terhadap Hasil Belajar Fisika SMA Pada Materi Penerapan Persamaan Gerak Harmonis Sederhana
}

\author{
Chairatul Umamah*, Maisyatul Azkiyah , Herman Jufri Andi , Suprianto \\ Program Studi Pendidikan Fisika, Universitas Islam Madura \\ *Email: chairatul.physics@gmail.com
}

Received: 25 November 2021; Accepted: 21 Desember 2021; Published: 23 Desember 2021

DOI: http://dx.doi.org/10.29303/jpft.v7i2.3165

\begin{abstract}
Absract - The purpose of this study are to determine whether there was a significant effect of the application of the Problem Solving Laboratory learning model on high school physics learning achievement and to identify improvements in high school physics learning achievement by using the Problem Solving Laboratory learning model. This research is a quasi-experimental research with nonequivalent control group design. The population of this study is the entire class $X$ even semester of MA Al-Islamiyah 1 Sumber Batu Blumbungan Larangan Pamekasan, while the samples are 2 classes XIPA consist of 22 students each selected using purposive sampling technique. Based on the results of hypothesis testing using the Independent Sample T-test test in the SPSS V. 25 program, obtained a value of $t_{\text {hitung }}>t_{\text {tabel }}(4.334>2.018)$ and a sig value $(2$-tailed $)=0.000$ or $<0.05$ so it can be concluded that there is a significant effect of application of the Problem Solving Laboratory learning model to high school physics learning achievements. The results of data analysis using the N-Gain test showed the Ngain value in the experimental class was 0.7823 or $G>0.7$. Thus, it is concluded that the improvement of high school physics learning achievements using the Problem Solving Laboratory learning model is in the high category.
\end{abstract}

Keyword: Problem Solving Laboratory Learning Model, High School; Physics Learning Outcome

\section{PENDAHULUAN}

Ilmu Pengetahuan Alam (IPA) pada hakikatnya tidak hanya terdiri dari ilmu pengetahuan saja, akan tetapi juga merupakan proses aktif menggunakan keterampilan untuk mempelajari alam melalui kegiatan ilmiah. Sehingga penyelenggaraan pembelajaaran fisika juga harus sesuai dengan hakikat IPA karena fisika merupakan sebagian dari mata pelajaran IPA. Hal tersebut sejalan dengan kurikulum 2013 yang menuntut pelaksanaan pembelajaran fisika dilakukan secara interaktif, inspiratif, menyenangkan, menantang, memotivasi siswa untuk berpartisipasi aktif, serta memberikan ruang yang cukup untuk prakarsa, kreativitas, dan kemandirian sesuai dengan bakat, minat, dan perkembangan fisik serta psikologis siswa. Pembelajaran fisika merupakan proses yang melibatkan pengembangan pola berpikir dan mengola logika pada suatu lingkungan belajar antara guru dan siswa yang sengaja diciptakan oleh guru dengan berbagai metode supaya program belajar fisika tumbuh dan berkembang secara optimal dan siswa dapat melakukan kegiatan belajar secara efektif dan efesien. Pembelajaran fisika yang diberikan tidak hanya untuk mentransfer ilmu pengetahuan akan tetapi sesuatu yang harus dipahami oleh peserta didik yang diperlukan dalam kehidupan sehari-hari ( Srilisnani et al., 2019).

Guru merupakan salah satu faktor yang mempengaruhi berhasil atau tidaknya suatu proses pembelajaran. Sehingga guru harus mampu menguasai prinsip-prinsip proses belajar mengajar, menciptakan kondisi belajar yang sebaik-baiknya dengan menggunakan model pembelajaran yang 
bervariasi dan disesuaikan dengan karakteristik konsep yang akan diajarkan untuk pembelajaran yang lebih efektif (Arisa et al., 2020).

Wieman \& Holmes, (2015) menyatakan bahwa salah satu tempat pembelajaran sains yang mampu membuat siswa mengkonstruk pengetahuan dan menemukan konsep fisika yang sedang dipelajari adalah laboratorium. Laboratorium merupakan bagian utama dari proses pembelajaran fisika, dengan adanya kegiatan fisika di laboratorium diharapkan siswa dapat terlibat langsung dalam proses pembelajaran. Sehingga siswa bisa memiliki memori jangka panjang dengan mengingat percobaan yang dilakukan di laboratorium.

Berdasarkan hasil wawancara terhadap guru mata pelajaran fisika di salah satu sekolah MA di Pamekasan menunjukkan bahwa model pembelajaran yang digunakan guru dalam pembelajaran di kelas masih kurang dalam melatih siswa untuk berpikir secara sistemastis, guru jarang melatih siswa untuk merancang penemuan sendiri (melakukan percobaan) sehingga kemampuan siswa untuk berpikir dan bertindak kreatif masih tergolong rendah.

Pemanfaatan laboratorium di sekolah masih belum dioptimalkan. Siswa kurang diberikan kesempatan untuk berproses dalam kegiatan percobaan sehingga hal tersebut akan mengakibatkan siswa melakukan kegiatan belajar tanpa menerapkan konsep yang sedang dipelajarinya. Kegiatan belajar mengajar seperti ini biasanya tidak disertai dengan semangat menemukan dan semangat bertanya. Dalam pelaksanaannya tidak ada diskusi mengenai berbagai gejala yang teramati atau yang terukur, sehingga hal tersebut akan berpengaruh terhadap hasil belajar siswa.
Salah satu model pembelajaran yang diharapkan bisa menghubungkan konsep yang sedang dipelajari siswa dengan kegiatan laboratorium adalah model pembelajaran Problem Solving Laboratory (PSL).

\section{Problem Solving Laboratory} merupakan model pembelajaran yang berorientasi pada keterlibatan siswa dalam proses belajarnya, dimana siswa dapat menggali pemecahan masalah secara kritis (Sujarwata, 2009). Siswa juga mendapat kesempatan untuk berperan aktif dan berproses dalam kegiatan belajar mengajar sehingga akan berdampak sangat besar terhadap hasil belajar siswa. Sedangkan menurut (Hariani, 2014), model pembelajaran Problem Solving Laboratory adalah model pembelajaran yang bertujuan untuk melatih keaktifan dan keefektifan siswa dalam proses pembelajaran dengan menggunakan kegiatan laboratorium. Pembelajaran diarahkan agar siswa dapat berpikir logis dan siswa dapat menyelesaikan masalah dari peristiwa nyata melalui kegiatan laboratorium. Heller, dalam penelitiannya mengungkapkan bahwa model pembelajaran Problem Solving Laboratory memiliki tujuan untuk mendukung konsep yang sedang dipelajari dalam kegiatan laboratorium.

Berdasarkan latar belakang diatas, rumusan masalah dari penelitian ini adalah: 1) Apakah terdapat perbedaan hasil belajar fisika SMA antara yang diajar menggunakan model pembelajaran Problem Solving Laboratory dengan model Direct Instructiont pada materi penerapan persamaan gerak harmonis sederhana? 2) Bagaimana peningkatan hasil belajar fisika SMA pada materi penerapan persamaan gerak harmonis sederhana dengan menggunakan model pembelajaran Problem Solving Laboratory? Sedangkan tujuan dari penelitian ini adalah: 1) Untuk 
mendeskripsikan perbedaan tingkat hasil belajar fisika SMA antara yang diajar menggunakan model pembelajaran Problem Solving Laboratory dengan model Direct Instructiont pada materi penerapan persamaan gerak harmonis sederhana 2) Untuk mengetahui peningkatan hasil belajar fisika SMA pada materi penerapan persamaan gerak harmonis sederhana dengan melalui model pembelajaran Problem Solving Laboratory.

\section{METODE PENELITIAN}

Teknik pengambilan sampel pada penelitian ini menggunakan porposive sampling. Purposive sampling adalah teknik penentuan sampel dengan pertimbangan tertentu Pada penelitian ini peneliti memilih karena mempertimbangkan aspek-aspek tertentu. Pengambilan sampel dengan teknik ini dilakukan dengan tujuan untuk menentukan kelas yang sudah ditentukan sesuai dengan tujuan penelitian. Sehingga peneliti dapat memperoleh hasil penelitian sesuai dengan prosedur yang telah dipilih dalam desain penelitian. Berdasarkan teknik sampling tersebut terpilih dua kelas yaitu $X$ IPA B dan X IPA C. Kelas X IPA C sebagai kelas eksperimen sedangkan kelas X IPA B sebagai kelas kontrol.

Desain penelitian yang akan digunakan adalah non-equivalent control group design. Desain ini dilakukan pada dua kelompok, yaitu kelompok eksperimen dan kelompok kontrol yang tidak dipilih secara random. Sebelum dilakukan perlakuan, pada kedua kelompok diberikan pretest untuk mengetahui sejauh mana kemampuan dasar siswa pada konsep gerak harmonis sederhana. Perlakuan dengan model problem solving laboratory diberikan pada kelas eksperimen saja, sedangkan kelas kontrol menggunakan model pembelajaran Direct Instructiont.
Teknik pengumpulan data merupakan cara untuk memperoleh data. Cara pengumpulan yang digunakan dalam penelitian ini adalah dengan tes. Tes terdiri dari pretest dan posttest. Sementara nontes dilakukan dengan observasi pada saat pelaksanaan penelitian.

Teknik analisis data yang digunakan untuk menjawab rumusan masalah adalah independent sample t-test dan uji $\mathrm{N}$-gain menggunakan aplikasi SPSS versi 25. Pertama, data diuji normalitas menggunakan uji Shapiro-wilk dengan SPSS versi 25 untuk mengetahui apakah sebaran data terdistribusi normal atau tidak.. Setelah data terbukti normal, maka dilakukan uji homogenitas menggunakan aplikasi SPSS versi 25 untuk mengetahui kehomogenitasan kedua sampel. Setelah data terbukti normal dan homogen, selanjutnya dilakukan uji hipotesis menggunakan independent sample t-test dengan SPSS versi 25. Hipotesis statistik yang digunakan yaitu:

Tabel 1. Kriteria Uji Hipotesis

\begin{tabular}{cc}
\hline Rentang Nilai t & Kategori \\
\hline$t_{\text {hitung }}>\mathrm{t}_{\text {tabel }}$ & $\mathrm{H}^{\mathrm{o}}$ ditolak dan $\mathrm{H}^{\mathrm{a}}$ \\
& diterima \\
$\mathrm{t}^{\text {hitung }}<\mathrm{t}^{\text {tabel }}$ & $\mathrm{H}^{\mathrm{o}}$ diterima dan $\mathrm{H}^{\mathrm{a}}$ \\
& ditolak \\
\hline
\end{tabular}

Kemudian, untuk mengetahui peningkatan hasil belajar fisika SMA dilakukan uji NGain. Dengan kategori sebagai berikut:

Tabel 2. Kategori Nilai N-Gain

\begin{tabular}{cc}
\hline Nilai $\boldsymbol{N}$-Gain & Kategori \\
\hline $\mathrm{G}>0,7$ & Tinggi \\
$0,3 \leq \mathrm{G} \leq 0,7$ & Sedang \\
$\mathrm{G}<0,3$ & Rendah \\
\hline
\end{tabular}

\section{HASIL DAN PEMBAHASAN}

\section{Hasil}

Penelitian ini dilakukan pada tanggal 3 Mei dan 14-17 Juni 2021 di MA AlIslamiyah 1 Sumber Batu Blumbungan 
Larangan Pamekasan. Penelitian ini merupakan penelitian eksperimen dengan dua variabel, yakni variabel bebas yaitu model pembelajaran Problem Solving Laboratory dan variabel terikat yaitu hasil belajar fisika SMA. Data penelitian ini terdiri dari tes awal (pretest) dan tes akhir (posttest) tentang materi Persamaan Gerak Harmonis Sederhana yang telah disampaikan dengan model pembelajaran Problem Solving Laboratory. Data hasil belajar siswa diperoleh dengan tes berbentuk pilihan ganda beralasan pada kelas eksperimen dan kelas kontrol.

Data nilai hasil belajar fisika diperoleh berdasarkan hasil pretest dan postest yang dilakukan pada dua kelas yaitu kelas X-IPA ${ }^{\mathrm{B}}$ dengan model Direct Instruction dan XIPA $^{\mathrm{C}}$ dengan model pembelajaran Problem Solving Laboratory. Deskripsi data hasil belajar fisika dapat dibaca pada Gambar 1 berikut:

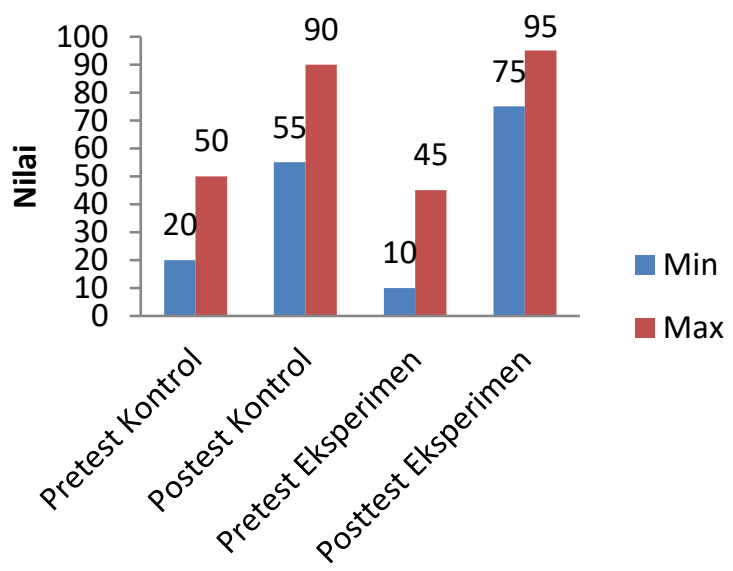

Gambar 1. Grafik Nilai Rata-rata Pretest dan Posttest Kelas Kontrol Dan Kelas Eksperimen

Pada Gambar 1 diketahui bahwa nilai rata-rata pretest kelas kontrol lebih tinggi dari kelas eksperimen. Peningkatan dan selisih nilai pretest posttest kedua kelas. Berdasarkan gambar tersebut, jelas bahwa peningkatan hasil belajar fisika kelas eksperimen lebih tinggi dari pada kelas kontrol.
Untuk menguji hipotesis penelitian, data pretest-posttest terlebih dahulu diuji normalitas dan homogenitas. Setelah data terbukti normal dan homogen, data dapat dilanjutkan pada tahap uji hipotesis. Uji normalitas data di lakukan dengan tujuan untuk menguji apakah semua kelompok data terdistribusi secara normal. Uji normalitas di lakukan terhadap data hasil belajar pada masing-masing kelompok, yaitu pada kelas eksperimen dan kelas kontrol. Ringkasan uji normalitas tertera pada Tabel 3 berikut:

Tabel 3. Ringkasan Hasil Uji Normalitas

\begin{tabular}{ccc}
\hline Test & Sig. & Keterangan \\
\hline Pretest Kontrol & 0,094 & Normal \\
Postest Kontrol & 0,385 & Normal \\
Pretest & 0,143 & Normal \\
$\begin{array}{c}\text { Eksperimen } \\
\text { Posttest }\end{array}$ & 0,200 & Normal \\
Eksperimen & & \\
\hline
\end{tabular}

Berdasarkan Tabel 3 diketahui bahwa hasil uji normalitas menggunakan uji shapirowilk menunjukan data hasil belajar siswa untuk kelas eksperimen dan kelas kontrol terdistribusi secara normal. Hal tersebut dikarenakan dasar pengambilan keputusan pada uji normalitas adalah "Jika nilai signifikansi (sig) > 0,05, maka data penelitian berdistribusi normal", sehingga data penelitian dapat dilanjutkan pada tahap uji homogenitas.

Uji homegenitas dilakukan untuk mengetahui apakah dua kelompok data yang diteliti memiliki varian yang homogen. Homogenitas varian diuji dengan menggunakan levene's test for equality of variances. Sebagai prasyarat untuk melanjutkan tahap uji hipotesis dengan menggunakan Independent Sample T-test. Hasil uji homogenitas serta uji hipotesis dapat dilihat pada Tabel 4 dan Tabel 5 berikut ini: 
Tabel 4. Hasil Uji Homogenitas dan Uji Hipotesis Nilai Pretest

\begin{tabular}{|c|c|c|c|c|c|}
\hline & \multicolumn{5}{|c|}{ Independent Samples T-test } \\
\hline & \multicolumn{2}{|c|}{$\begin{array}{l}\text { Levene's Test } \\
\text { for Equality } \\
\text { of Variances }\end{array}$} & \multicolumn{3}{|c|}{$\begin{array}{c}\text { T-test for Equality } \\
\text { of Means }\end{array}$} \\
\hline & $F$ & Sig. & $T$ & $D f$ & $\begin{array}{c}\text { Sig. } \\
\text { (2- } \\
\text { taile } \\
\text { d) }\end{array}$ \\
\hline Hasil & 0,02 & $\mathbf{0 , 8 7}$ & - & 42 & 0,17 \\
\hline Belajar & 6 & 2 & 3,30 & & 9 \\
\hline Fisika & & & 5 & & \\
\hline
\end{tabular}

Tabel 5. Hasil Uji Homogenitas dan Uji Hipotesis Nilai Posttest

\begin{tabular}{|c|c|c|c|c|c|}
\hline & \multicolumn{5}{|c|}{ Independent Samples T-test } \\
\hline & \multicolumn{2}{|c|}{$\begin{array}{l}\text { Levene's Test } \\
\text { for Equality } \\
\text { of Variances }\end{array}$} & \multicolumn{3}{|c|}{$\begin{array}{c}\text { T-test for Equality } \\
\text { of Means }\end{array}$} \\
\hline & $\boldsymbol{F}$ & Sig. & $T$ & $D f$ & $\begin{array}{c}\text { Sig. } \\
(2- \\
\text { taile } \\
\text { d) }\end{array}$ \\
\hline Hasil & 0,10 & $\mathbf{0 , 7 4}$ & 4,33 & 42 & $\mathbf{0 , 0 0}$ \\
\hline $\begin{array}{c}\text { Belajar } \\
\text { Fisika }\end{array}$ & 9 & 3 & 4 & & $\mathbf{0}$ \\
\hline
\end{tabular}

Pada Tabel 4 diketahui bahwa pada nilai pretest, nilai $t_{\text {hitung }}=-3,305$ dan nilai signifikan (2-tailed) $=0,179$. Nilai distribusi $t_{\text {tabel }}$ dapat dilihat berdasarkan $\mathrm{df}=42$ dengan taraf signifikan $\alpha=0,05$, sehingga $t_{\text {tabel }}=2,018$. Dari perhitungan tersebut dapat diketahui bahwa nilai $t_{\text {hitung }}<t_{\text {tabel }}$ ($3,305<2,018)$ dan nilai signifikan (2-tailed) $>0,05(0,179<0,05)$. Mengacu pada dasar pengambilan keputusan dalam uji Independent Sample T-test, maka pada nilai pretest $\mathrm{H}_{1}$ ditolak dan $\mathrm{H}_{0}$ diterima. Hipotesis yang diterima adalah hipotesis nihil yakni tidak terdapat pengaruh yang signifikan dari penggunaan model pembelajaran Problem Solving Laboratory terhadap hasil belajar fisika SMA pada materi penerapan persamaan gerak harmonis sederhana. Hal ini disebabkan karena sebelum pemberian soal pretest tidak diterapkan model pembelajaran Problem Solving Laboratory.

Sedangkan pada Tabel 5, diketahui bahwa pada nilai posttest, nilai $t_{\text {hitung }}=$
4,334 dan nilai signifikan (2-tailed $)=0,000$.

Nilai distribusi $t_{\text {tabel }}$ dapat dilihat berdasarkan $\mathrm{df}=42$ dengan taraf signifikan $\alpha=0,05$, sehingga $t_{\text {tabel }}=2,018$. Dari perhitungan tersebut dapat diketahui bahwa nilai $t_{\text {hitung }}>t_{\text {tabel }}(4,334>2,018)$ dan nilai signifikan (2-tailed) $<0,05(0,000<$ $0,05)$. Mengacu pada dasar pengambilan keputusan dalam uji Independent Sample Ttest, maka pada nilai posttest $\mathrm{H}_{0}$ ditolak dan $\mathrm{H}_{1}$ diterima. Hal ini menyatakan bahwa pembelajaran Problem Solving Laboratory memiliki peran dalam peningkatan hasil belajar peserta didik. Karena pada dasarnya pembelajaran Problem Solving Laboratory menuntun peserta didik untuk mandiri dalam melakukan sendiri aktivitas aktivitas berbasis sains sehingga peserta didik terbiasa untuk melakukan hal tersebut mengakibatkan kelihaian dan keterampilanketerampilan dalam menjawab soal fisika semakin meningkat karena adanya sikap kemadirian tersebut sehingga secara langsung hasil belajar juga terus meningkat

Sedangkan untuk mengetahui besarnya peningkatan hasil belajar siswa pada kelas kontrol dan kelas eksperimen, peneliti menggunakan uji N-Gain. Perhitungan N-Gain dilakukan dengan menggunakan program IBM SPSS Versi 25 yang hasil perhitungannya adalah sebagai berikut:

Tabel 6. Ringkasan Hasil Perhitungan N-Gain

\begin{tabular}{ccc}
\hline Variabel & N-Gain & Kategori \\
\hline Kontrol & 0.6122 & Sedang \\
Eksperimen & 0,7823 & Tinggi \\
\hline
\end{tabular}

Berdasarkan Tabel 6 dapat diketahui bahwa pada kelas kontrol, nilai $\mathrm{g}=0,6122$, dengan $0,3 \leq \mathrm{g}<0,7$ dengan demikian peningkatan hasil belajar fisika pada kelas kontrol berada pada kategori sedang. Sedangkan pada kelas eksperimen diketahui bahwa nilai $\mathrm{g}=$ 0,78823 , dengan $\mathrm{g} \geq 0,7$ maka peningkatan 
hasil belajar fisika pada kelas eksperimen berada pada kategori tinggi.

\section{Pembahasan}

Penelitian ini dilakukan untuk mengetahui pengaruh penerapan model pembelajaran Problem Solving Laboratoty terhadap hasil belajar fisika SMA pada materi penerapan persamaan gerak harmonis sederhana pada kelas eksperimen dan kelas kontrol. Kelas X IPA ${ }^{\mathrm{B}}$ sebagai kelas kontrol sedangkan kelas $\mathrm{X}$ IPA $^{\mathrm{C}}$ sebagai kelas eksperimen. Letak perbedaan antara kedua kelas tersebut adalah penggunaan model pembelajaran. Pada kelas eksperimen, model pembelajaran yang digunakan adalah model pembelajaran Problem Solving Laboratory. Sedangkan pada kelas kontrol, model pembelajaran yang digunakan adalah model Direct Instruction.

Instrumen yang digunakan untuk mengetahui hasil belajar siswa adalah soal pilihan ganda beralasan yang telah di judgement oleh kelompok ahli dan telah dinyatakan valid untuk digunakan dalam penelitian. Kedua kelas diberikan tes awal (pretest) sebelum diberikan perlakuan dan tes akhir (posttest) setelah diberikan perlakuan. Berdasarkan hasil pretest kelas kontrol dan kelas eksperimen diperoleh nilai rata-rata masing-masing kelas sebesar 32,73 dan 23,64, nilai ini dikatan cukup rendah dibandingkan nilai maksimal (100). Hal tersebut dikarenakan kedua kelas belum mempelajari materi persamaan gerak harmonis sederhana sebelumnya, sehingga siswa kesulitan untuk memahami soal pretest yang diberikan.

Setelah didapatkan nilai pretest, kedua kelas diberikan perlakuan berupa model Direct Instruction pada kelas kontrol dan model pembelajaran Problem Solving Laboratory pada kelas eksperimen dan kemudian diberikan tes akhir (posttest). Hasil posttest menunjukkan adanya perubahan nilai pada kedua kelas, yaitu nilai rata-rata 74,09 pada kelas kontrol dan 83,64 pada kelas eksperimen.

Data nilai hasil pretest posttest tersebut kemudian diuji normalitas menggunakan SPSS V.25. Kedua kelas memiliki nilai signifikansi lebih dari 0,05, sehingga dapat disimpulkan bahwa data hasil penelitian kedua kelas tersebut terdistribusi normal. Setelah diketahui data terdistribusi normal, selanjutnya dilakukan uji homogenitas menggunakan SPSS V.25 untuk mengetahui kehomogenan kedua sampel. Berdasarkan uji tersebut, didapatkan nilai signifikansi lebih dari 0,05 sehingga kedua sampel dinyatakan homogen.

Data yang telah terbukti normal dan homogen kemudian dilanjutkan pada uji hipotesis atau uji-T menggunakan uji Independent Sample T-test. Bedasarkan uji tersebut didapatkan nilai $t_{\text {hitung }}>t_{\text {tabel }}$ dan nilai Sig. (2-tailed) $<0,05$ sehingga $\mathrm{H}_{0}$ ditolak dan $\mathrm{H}_{1}$ diterima. Hal ini dapat diartikan bahwa terdapat pengaruh yang signifikan pada hasil belajar fisika SMA pada kelas yang diterapkan model Problem Solving Laboratory.

Untuk mengetahui adanya peningkatan hasil belajar fisika dilakukan uji $\mathrm{N}$-gain dengan menggunakan nilai hasil pretest posttest kedua kelas. Dari data tersebut dapat ditarik kesimpulan bahwa peningkatan hasil belajar fisika pada kelas eksperimen lebih unggul daripada peningkatan hasil belajar fisika pada kelas kontrol. Hal tersebut dapat dilihat dari nilai Gain pada kelas eksperimen yaitu 0,7823 atau $\mathrm{G}>0,7$ berada pada kategori tinggi. Sedangkan pada kelas kontrol, nilai Gain yaitu 0,6122 atau $0,3 \leq \mathrm{G} \leq 0,7$ berada pada kategori sedang. Adanya keunggulan tersebut dikarenakan penerapan model pembelajaran Problem Solving Laboratory lebih mendominasi peran aktif siswa dalam 
menyelesaikan lembar kerja siswa (LKS) dari pada model Direct Instruction.

Model pembelajaran Problem Solving Laboratory merupakan model pembelajaran yang berorientasi terhadap keterlibatan siswa dalam proses pembelajaran yang dilakukan di laboratorium. Proses penyelesaian permasalahan di laboratorium membuat siswa dapat melihat fakta yang terjadi secara langsung, sehingga proses terciptanya pengetahuan dilakukan dengan inisiatif siswa sendiri.

Hasil penelitian ini menunjukkan bahwa terdapat perbedaan hasil belajar fisika siswa antara model pembelajaran Problem Solving Laboratory dengan model direct instruction sehingga dapat disimpulkan bahwa model pembelajaran Problem Solving Laboratory memiliki pengaruh yang signifikan terhadap hasil belajar fisika SMA dan lebih efektif untuk meningkatkan hasil belajar fisika SMA. Hal ini sejalan dengan hasil penelitian yang dilakukan Fitri Hariani (2014) yang menyatakan bahwa model pembelajaran Problem Solving Laboratory memberikan pengaruh yang signifikan terhadap hasil belajar fisika siswa pada materi elastisitas, yakni dengan uji-T sebesar 2,701. Selain itu, hasil penelitian Sujarwata (2009) mengungkapkan bahwa model pembelajaran problem solving laboratory meningkatkan hasil belajar pada mata kuliah elektronika dasar II.

\section{PENUTUP}

Berdasarkan penelitian yang telah dilakukan, dapat disimpulkan bahwa Terdapat perbedaan hasil belajar fisika SMA antara yang diajar menggunakan model pembelajaran Problem Solving Laboratory dengan model Direct Instructiont pada materi penerapan persamaan gerak harmonis sederhana Hal ini dapat dilihat dari hasil uji Independent Sample T-test yang menunjukkan nilai $t_{\text {hitung }}>t_{\text {tabel }}$ yaitu
4,334 > 2,018 dan nilai Sig. (2-tailed) $<0,05$ yakni 0,000. Sedangkan peningkatan hasil belajar fisika SMA pada materi penerapan persamaan gerak harmonis sederhana dengan menggunakan model pembelajaran Problem Solving Laboratory berada pada kategori tinggi. Hal ini dapat dilihat dari hasil uji N-Gain yang menunjukkan nilai $\mathrm{G}$ $>0,7(\mathrm{G}=0,78823)$.

\section{UCAPAN TERIMAKASIH}

Penelitian ini dapat terlaksana dengan baik karena bantuan berbagai pihak, oleh karena itu, apresiasi dan terimakasih penulis sampaikan kepada seluruh pihak yang telah membantu jalannya penelitian ini.

\section{REFERENSI}

Arisa, N., Johansyah, \& Hanif, M. K. A. (2020). Keefektifan Model Pembelajaran Novick Terhadap Pemahaman Konsep Fisika Siswa SMK Negeri 17 Samarinda Materi Elastisitas dan Hukum Hooke. Jurnal Literasi Pendidikan Fisika, 1(01), 4555.

Azizah, N., \& Edie, S. S. (2014). Pendekatan Problem Solving Laboratory Untuk Meningkatkan Kreatifitas Dan Hasil Belajar Siswa Kelas XI MA Al Asror Gunungpati Semarang. UPEJ Unnes Physics Education Journal, 3(3), Article 3. https://doi.org/10.15294/upej .v3i3.4328.

Ellianawati -, \& Subali, B. (2010). Penerapan Model Praktikum Problem Solving Laboratory Sebagai Upaya Untuk Memperbaiki Kualitas Pelaksanaan Praktikum Fisika Dasar. Jurnal Pendidikan Fisika Indonesia, 6(2), Article 2. 
https://doi.org/10.15294/jpfi. v6i2.1119.

Fadli, A. R., Subiki, S., \& Astutik, S. (2019). Pengaruh Model Pembelajaran Problem Solving Laboratory Terhadap Kemampuan Berpikir Kritis Fisika Siswa di MAN 2 Banyuwangi. Jurnal Pembelajaran Fisika, 8(2), 53-58.

https://doi.org/10.19184/jpf.v 8i2.11138.

Hariani, F. (2014). Program Studi Pendidikan Fisika Jurusan Pendidikan Mipa Fakultas Keguruan Dan Ilmu Pendidikan Universitas Jember 2014. 7.

Hasnawati, -. (2006). Pendekatan Contextual Teaching Learning Hubungannya dengan Evaluasi Pembelajaran. Jurnal Ekonomi dan Pendidikan, 3(1), Article 1. https://doi.org/10.21831/jep. v3i1.635.

Kurdi, \& Nuraini, F. (2019). Penerapan Student Centered Learning Mata Ajar Ilmu Kesehatan Pada Program Studi Penjaskes. Jurnal Forum Kependidikan, 28 (2).

Malik, A., \& Handayani, W. (2015). Model Praktikum Problem Solving Laboratory untuk Meningkatkan Keterampilan Proses Sains Mahasiswa. 4.

Mukrima. (2016). Peningkatan Hasil Belajar Fisika Melalui Pendekatan Kontruktivisme dengan Metode Siklus Belajar Karplus pada Siswa kelas XI IPA 3 SMA Negeri 1 POLUT (Polungbangkeng Utara) Kab. Takalar. Universitas Islam Negeri Alauddin Makasar.
Sari, Suci Wulan, (2011). Pengaruh Model Pembelajaran dan Tipe Kepribadian Siswa Terhadap Hasil Belajar Fisika Pada SMP Swasta Di Kecamatan Medan Area Dalam. http://library.unimed.ac.id.

Srilisnani, Amin, A., \& Yolanda, Y. (2019). Penerapan Model Pembelajaran Contextual Teaching And Learning (CTL) Terhadap Aktivitas Siswa Kelas X di SMA Negeri 5 Model Lubuklinggau Tahun Pelajaran 2018/2019. Silampari Jurnal Pendidikan Ilmu Fisika, 1(1), 60-73. https://doi.org/10.31540/sjpif .v1i1.319.

Sudjana. (2005). Metode Statistika. Bandung: Tarsito.

Sujarwata, -. (2009). Peningkatan Hasil Belajar Elektronika Dasar II Melalui Penerapan Model Pembelajaran Problem Solving Laboratory. Jurnal Pendidikan Fisika Indonesia, 5(1). https://doi.org/10.15294/jpfi. v5i1.998.

Wieman, C., \& Holmes, N. G. (2015). Measuring The Impact of An Instructional Laboratory On The Learning Of Introductory Physics. American Journal of Physics, 83(11), 972-978. https://doi.org/10.1119/1.493 $\underline{1717}$ 